\title{
Enhancement Techniques of Parabolic Trough Collectors: A Review of Past and Recent Technologies
}

ISSN: 2639-0574

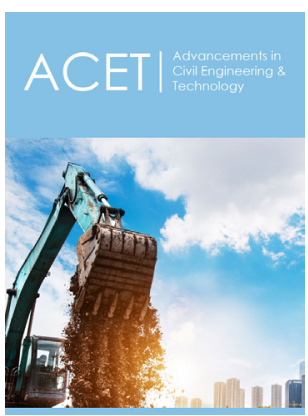

${ }^{* 1}$ Corresponding author: Imran Afgan, Modelling and Simulation Centre, School of MACE, University of Manchester, M13 9PL, UK

Submission: 眥June 10, 2019

Published: 海June 13, 2019

Volume 3 - Issue 3

How to cite this article: Nabeel A, Imran A. Enhancement Techniques of Parabolic Trough Collectors: A Review of Past and Recent Technologies. Adv Civil Eng Tech. 3(3). ACET.000563.2019.

DOI: 10.31031/ACET.2019.03.000563

Copyright@ Imran Afgan, This article is distributed under the terms of the Creative Commons Attribution 4.0 International License, which permits unrestricted use and redistribution provided that the original author and source are credited.

\section{Nabeel Abed and Imran Afgan*}

Modelling and Simulation Centre, School of MACE, University of Manchester, UK

\begin{abstract}
Parabolic Trough Collectors (PTC) are one of the most widely used technology amongst the solar thermal systems used by the power generation industry. In recent years, numerous scientific investigations have focused on this topic to assess the thermal performance and to improve its thermal efficiency. The current paper presents a short but concise review of the PTC system showing the recent and past studies in a quest to improve and enhance the thermal and optical efficiencies. We discuss briefly the techniques used for single and two-phase flow modelling, design variables and experimental processes. Furthermore, studies investigating the enhancement of thermal performance are critically summarized such as: use of nanofluids as a working fluid and passive heat transfer enhancement techniques (inserts for the solar receiver).
\end{abstract}

Keywords: Nanofluids; Parabolic trough collector; Passive heat transfer enhancements; Solar thermal energy

\section{Introduction}

To tackle the climate change and global warming, the world needs to reduce its dependency on fossil fuels. In recent years clean, renewable and sustainable sources of energy such as solar, wind, tidal etc. have thus become widely popular. In particular solar thermal energy has emerged as a major contender in the quest to reduce $\mathrm{CO}_{2}$ emissions especially for regions with hot tropical climate. The light or solar energy/heat from the sun can be harnessed to produce electricity via Photovoltaic Devices (PV) or Concentrating Solar Power (CSP) plants. The CSP plants operate on Direct Normal Irradiance (DNI), which is defined as the amount of received solar energy per unit area on the surface held normal to the rays of the sun. Depending upon the methodology to capture the suns energy, the CSP technology can be categorized into several technologies, four of the most common ones being; parabolic trough collectors (PTC: which is our focus), linear Fresnel reflectors, parabolic dishes and solar towers, in Figure 1.

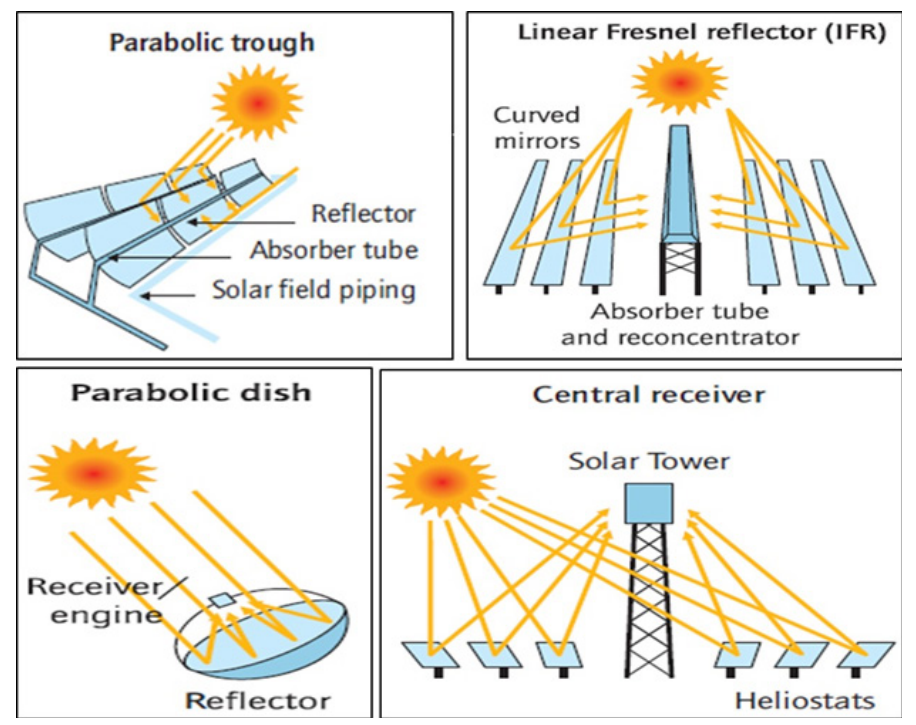

Figure 1: Current CSP types, Philibert and Frankl [1]. 
The PTC system consists mainly of three important sub-systems; the solar field, the storage system and the power block. The solar field can be categorized as a type of a large heat exchanger with the main components being the solar collector and the reflector surface. The reflector surface is generally made up of a series of mirrors that directs the solar energy to the solar collector. The solar collector then converts the absorbed incident solar radiation into thermal energy which is carried through the collector via the Heat Transfer Fluid (HTF). Within the solar collector, an absorber tube is generally made from a metal which is coated with black color to achieve larger solar absorbance and to reduce the thermal emittance. The absorber tube is encased within a glass envelope which is itself covered with an anti-reflective coating to reduce the heat losses by convection.

\section{Thermal performance of PTCs}

The absorber tube (also known as heat collection element (HCE)) is one of the most important elements in a PTC system; its thermal efficiency directly impacts not just the reliability of the plant but also the cost of energy production. Because of these reasons various methodologies of heat transfer enhancement are generally used within the absorber tube for the PTC system. The most commonly used techniques such as, changing the working fluid, use of nanoparticles and the use of inserts (swirl generators etc.), are reviewed below. A fourth methodology which is based on combination of nanoparticles with inserts is also becoming popular.

\section{Thermal performance by changing working fluids}

Majority of the solar thermal power plants (STPP) with PTC systems around the world which are currently operational use thermal oil as HTF with the maximum working temperature of $398{ }^{\circ} \mathrm{C}$. Low vapour pressure, affordable price, long lifetime and good thermal stability are the obvious reasons for using thermal oils in the STPP. However, this does not mean that thermal oils are the best working fluid; limitation of temperature (around $400{ }^{\circ} \mathrm{C}$ ), environmental toxicity and flammability are some of the key drawbacks when using thermal oils. Alternative HTFs that have been examined in the literature instead are; liquidwater/steam, pressurized gases and molten salts. Some of these investigations and their key findings highlighting the advantages and disadvantages compared to thermal oils typically used in the STPP are summarized in Table 1.

Table 1: Effects of changing Heat Transfer Fluid (HTF) on the thermal performance.

\begin{tabular}{|c|c|c|}
\hline Ref. & Working Fluid & Details of Findings \\
\hline [2] & Syltherm 800 oil and water & $\begin{array}{l}\text { Thermal loss of the collector was lower when using water than those predicted by using } \\
\text { Syltherm } 800 \text { oil. }\end{array}$ \\
\hline$[3]$ & $\begin{array}{l}\text { Therminol VP1, Xceltherm 600, Syltherm 800, } \\
\text { 60-40 Salt, and Hitec XL Salt }\end{array}$ & $\begin{array}{l}\text { Effect of working fluid was smaller than other parameters. The maximum thermal effi- } \\
\text { ciency was provided by Xceltherm } 600 \text { and Syltherm 800, but these fluids are relatively } \\
\text { expensive. }\end{array}$ \\
\hline$[4]$ & Molten salt, water, oil & Better efficiency has been obtained by using water. \\
\hline [5] & $\begin{array}{l}\text { Syltherm 800, XLT, Santotherm 59, Marlo- } \\
\text { therm X, and Therminol D12. }\end{array}$ & $\begin{array}{l}\text { The Syltherm } 800 \text { can be operated at a temperature higher than } 700 \mathrm{~K} \text {, while the working } \\
\text { fluids marlotherm X and syltherm XLT can only be operated at a temperature less than } \\
\text { 700K; whereas, others can operate between } 650 \mathrm{~K} \text { and } 750 \mathrm{~K} \text {. }\end{array}$ \\
\hline$[6]$ & $\begin{array}{l}\text { Syltherm 800, XLT Santotherm 59, LT, Marlo- } \\
\text { therm X, Therminol D12, and Marlotherm SH. }\end{array}$ & $\begin{array}{l}\text { The most appropriate choice was Syltherm } 800 \text { which provided the maximum range of } \\
\text { (700-800) K. The highest cost when using Santotherm LT was } 129 \mathrm{US} \$ / \mathrm{kW} \text { h/day. More- } \\
\text { over, the best HTF was Syltherm } 800 \text { from the thermal capacity point of view. }\end{array}$ \\
\hline$[7]$ & Pressurized nitrogen and synthetic oil & $\begin{array}{l}\text { A slight difference in the net electrical power between fluids, only }(-0.91 \%) \text {, while the } \\
\text { gross electrical production per year was the same. }\end{array}$ \\
\hline$[8]$ & Gas & $\begin{array}{c}\text { The highest temperature reached by the gas was } 400^{\circ} \mathrm{C} \text { which cannot be reached by the } \\
\text { synthetic oil. }\end{array}$ \\
\hline [9] & $\begin{array}{l}\text { Molten salt compared with the results of } \\
\text { PTR70 }\end{array}$ & $\begin{array}{l}\text { It was deduced that the heat loss of the examined tube using PTR70 is smaller than that of } \\
\text { using molten salt. }\end{array}$ \\
\hline [10] & $\left(\mathrm{S}-\mathrm{CO}_{2}\right)$ using Rankine and Brayton cycles & $\begin{array}{l}\text { The collector efficiency in two cycles increased to } 81.93 \%-84.7 \% \text { (Rankine cycle) and } \\
18.78 \%-84.17 \% \text { (Brayton cycle). }\end{array}$ \\
\hline [11] & Thermal oil, water & The performance obtained by water was better than that measured by oil. \\
\hline$[12]$ & $\begin{array}{l}\text { Pressurized water, Therminol VP-1, nitrate } \\
\text { molten salt, sodium liquid, air, } \mathrm{CO}_{2} \& \text { helium. }\end{array}$ & $\begin{array}{c}\text { The performance of liquids was higher than that of gases. The pressurized water is the } \\
\text { most appropriate fluid for temperature up to } 500 \mathrm{~K} \text { while sodium liquid is better for tem- } \\
\text { peratures up to } 1100 \mathrm{~K} \text {. }\end{array}$ \\
\hline
\end{tabular}




\section{Thermal performance by adding nanoparticles}

One of the most commonly used technique to improve the thermal performance in PTCs is to add metallic or non-metallic nanoparticles inside the base working fluid; the mixture then referred to as nanofluid. These nanoparticles having different thermal properties than that of the base fluid results in a more efficient nanofluid thereby improving the overall thermal performance of the absorber system. Besides this, the nanoparticles also help in the reduction of the thermal stresses inside the absorber tube. However, agglomeration of nanoparticles in certain parts of the system results in higher pressure drops with raised power pumping requirements. To overcome this problem, the volume fraction of nanoparticles needs to be optimized for efficient heat transfer augmentation. A summarized review of previous studies is shown in Table 2 illustrating the use of nanofluids in the PTCs. Numerical modelling approaches either treat the nanofluids as a single phase or a two-phase model; the latter being more accurate. However, regardless of the treatment, the selection of thermos-physical properties of the nanoparticles is of paramount importance.

Table 2: Effects of nanoparticles Concentration Ratio (CR) on the thermal performance of Parabolic Trough Collector (PTC).

\begin{tabular}{|c|c|c|c|c|}
\hline Ref. & $\mathbf{N p}$ & HTF & (CR) (\%) & Main Achievements \\
\hline$[13]$ & $\mathrm{Al}_{2} \mathrm{O}_{3}$ & Ionic Liquids & $0.18,0.36,0.9$ & $\begin{array}{l}0.9 \% \text { of CR, thermal conductivity enhanced by about } 11 \% \text { and heat } \\
\text { capacity by } 49 \% \text {. }\end{array}$ \\
\hline$[14]$ & $\mathrm{Al}_{2} \mathrm{O}_{3}$ & synthetic oil & $0,1,2,3,4,5$ & $\begin{array}{l}11.5 \% \text { and } 36 \% \text { increase in the heat transfer coefficient (HTC) using } \\
5 \% \text { of CR for single-phase and two-phase model respectively. }\end{array}$ \\
\hline$[15]$ & $\mathrm{Al}_{2} \mathrm{O}_{3}$ & synthetic oil & $1,3,5$ & $\begin{array}{l}\text { Considerable increase in the heat transfer coefficient recorded with } \\
\text { increasing CR. }\end{array}$ \\
\hline$[16]$ & $\mathrm{Al}_{2} \mathrm{O}_{3}$ & synthetic oil & $0-4,0-6,0-8$ & $\begin{array}{l}\text { The thermal efficiency reached } 76 \% \text { with CR of } 8 \% \text { and the max- } \\
\text { imum efficiency was recorded at the smallest temperature and } \\
\text { minimum Renumber. }\end{array}$ \\
\hline$[17]$ & $\mathrm{CuO}-\mathrm{Al}_{2} \mathrm{O}_{3}$ & water & $\begin{array}{l}\text { CuO:0.1-0.3 } \\
\text { Al2O3: } 4,6,8\end{array}$ & $\begin{array}{l}\text { The extinction coefficient increased with increasing the CR of } \\
\text { nanoparticles. }\end{array}$ \\
\hline$[18]$ & $\mathrm{Al}_{2} \mathrm{O}_{3}$ & Sylthem 800 & $0-4$ & $\begin{array}{l}10 \% \text { enhancement was obtained in the collector efficiency at CR of } \\
4 \% .\end{array}$ \\
\hline$[19]$ & $\mathrm{NiO}$ & $\begin{array}{l}\text { Biphenyl, diphenyl } \\
\text { oxide }\end{array}$ & Wt\%: $(1,5,10) 10^{-4}$ & $\begin{array}{l}\text { Increasing the heat transfer coefficient up to } 50 \% \text { and thermal } \\
\text { conductivity up to } 96 \% \text {. }\end{array}$ \\
\hline$[20]$ & $\mathrm{CuO}+-\mathrm{Al}_{2} \mathrm{O}_{3}$ & Water, water-EG & $0.05,0.1,0.2$ & $\begin{array}{l}\text { The thermal efficiency is higher in the case of dispersing only in wa- } \\
\text { ter since the mixture of water-EG has a disadvantage of boiling and } \\
\text { freezing temperature which is higher than those of pure water. }\end{array}$ \\
\hline$[21]$ & $\mathrm{Al}_{2} \mathrm{O}_{3}$ & synthetic oil & $0,0.01,0.03,0.05$ & $\begin{array}{l}\text { The absorber deformation decreased moderately from } 2.11 \mathrm{~mm} \text { to } \\
\text { only } 0.54 \mathrm{~mm} \text { by increasing the CR to } 0.05 \% \text {. }\end{array}$ \\
\hline$[22]$ & $\begin{array}{l}\mathrm{Al}_{2} \mathrm{O}_{3} \\
\mathrm{Fe}_{2} \mathrm{O}_{3}\end{array}$ & water & $0.20,0.25,0.30$ & $\begin{array}{l}\text { The thermal efficiency enhanced by } 13 \% \text { and } 11 \% \text { respectively, } \\
\text { higher than the pure fluid. }\end{array}$ \\
\hline$[23]$ & $\mathrm{TiO}_{2}$ & water & $0.05,0.1,0.2$ & The thermal efficiency enhanced by $8.66 \%$ at CR of $0.2 \%$. \\
\hline$[24]$ & MWCNT & oil & $0.2,0.3$ & $\begin{array}{l}\text { The thermal efficiency enhancement was } 5-7 \% \text { when using CR of } \\
\qquad 0.2 \% \text {. }\end{array}$ \\
\hline$[25]$ & $\mathrm{Al}_{2} \mathrm{O}_{3}, \mathrm{CuO}, \mathrm{TiO}_{2}$ & Syltherm 800 & 3,5 & $\begin{array}{l}\text { The thermal efficiency enhanced by } 1.46,1.25 \text {, and } 1.40 \text { using } \mathrm{Al}_{2} \mathrm{O}_{3} \text {, } \\
\qquad \mathrm{CuO} \text {, and } \mathrm{TiO}_{2} \text {, respectively. }\end{array}$ \\
\hline$[26]$ & $\mathrm{Cu}$ & Therminol @VP-1 & $0,1,2,4,6$ & $\begin{array}{c}\text { At CR } 6 \% \text {, Heat transfer rate and the system thermal efficiency } \\
\text { enhanced by } 32 \% \text { and } 12.5 \% \text { respectively, whereas, the entropy } \\
\text { generation decreased up to } 20-30 \% \text {. }\end{array}$ \\
\hline
\end{tabular}




\section{Effects of swirl generators on the thermal performance}

The usage of swirl generators inside a receiver is a passive method that is used to enhance the convective heat transfer rate. These devices could be twisted tapes, fins, coils, wires and spiral grooved tubes etc. The flow in such devices has important features such as; intense mixing of the near-wall region flows with main- stream flow and reduction of the thermal boundary layer. Improved overall thermal efficiency of the PTC, cost minimization and improvement in the system reliability are added further benefits of such passive enhancers. A comprehensive summary of such inserts is presented in Table 3 including the enhancement of both thermal and optical performances.

Table 3: Effects of insert types.

\begin{tabular}{|c|c|c|c|c|c|c|c|}
\hline \multirow[b]{2}{*}{ Ref. } & \multirow[b]{2}{*}{ Typical output } & \multicolumn{6}{|c|}{ Enhancements by Inserting Swirl Generators Compared with the Typical Receiver } \\
\hline & & $\begin{array}{c}\text { Gain in Out- } \\
\text { put }\end{array}$ & Type 1 & $\begin{array}{c}\text { Gain in Out- } \\
\text { put }\end{array}$ & Type 2 & $\begin{array}{l}\text { Gain in } \\
\text { Output }\end{array}$ & Type 3 \\
\hline [27] & $\eta$ th (\%): 57.21- 66.96 & $58.98-67.59$ & Bottom insert & 59.41-67.78 & U-shaped & $60.5-67.43$ & Inclined insert \\
\hline [28] & $\begin{array}{l}\mathrm{Nu}(\%) \\
\mathrm{FF}(\%)\end{array}$ & $\mathrm{Nu}(\%): 37 \%$ & $\begin{array}{l}\text { Twisted tape } \\
\text { (TT) }\end{array}$ & $\begin{array}{l}\mathrm{Nu} \& \mathrm{FF} 150 \\
\quad \& 210\end{array}$ & louvered TT & - & - \\
\hline [29] & Nu: $229.46-1286.37$ & $\begin{array}{c}\text { Nu: } 374.63- \\
1766.11\end{array}$ & Porous rings & - & - & - & - \\
\hline [30] & $\begin{array}{l}\text { Nu \& Thermal } \\
\text { performance }\end{array}$ & $9 \% \& 12 \%$ & $\begin{array}{l}\text { Arrays of pin } \\
\text { fins }\end{array}$ & - & - & - & - \\
\hline [31] & Nu: $229.46-1286.37$ & $\begin{array}{c}\text { Nu: 318.41- } \\
1501.22\end{array}$ & $\begin{array}{l}\text { Two segmen- } \\
\text { tal rings }\end{array}$ & $\begin{array}{c}\text { Nu: } 337.87- \\
1613.77\end{array}$ & $\begin{array}{l}\text { Three segmental } \\
\text { rings }\end{array}$ & - & - \\
\hline [32] & HTC \& pressure drop (PD) & $\begin{array}{l}490-2200 \& \\
\text { Up to } 1850\end{array}$ & $\begin{array}{l}\text { Trapezoidal } \\
\text { fins }\end{array}$ & $\begin{array}{l}500-2300 \& \\
\text { Up to } 2400\end{array}$ & Circular fins & $\begin{array}{l}490-2200 \& \\
\text { Up to } 1600\end{array}$ & Triangular Fins \\
\hline [33] & $\mathrm{Nu}(\%)$ & 16 & $\begin{array}{c}\text { TT \& } 0.3 \% \text { of } \\
\mathrm{Al}_{2} \mathrm{O}_{3}\end{array}$ & 20 & $\begin{array}{l}\text { Nail TT \& } 0.3 \% \\
\mathrm{Al}_{2} \mathrm{O}_{3}\end{array}$ & - & - \\
\hline [34] & HTC (\%) \& Entropy generation & $\begin{array}{l}25.53 \& \\
-29.1 \%\end{array}$ & Dimpled TT & $\begin{array}{l}58.96 \& \text { F.F } \\
5.05 \%\end{array}$ & $\begin{array}{l}\text { Dimpled TT \& } \\
\mathrm{Al}_{2} \mathrm{O}_{3}\end{array}$ & - & - \\
\hline [35] & $\mathrm{Nu}$ (times) \& FF (times) & $1.3-1.8 \& 1.66$ & Triangular fins & $1.3-1.8 \& 1.57$ & Rectangular fins & - & - \\
\hline [36] & Exegetic performance \& $\eta$ th & $\begin{array}{c}42.7 \% \\
\& 70.82 \%\end{array}$ & $\begin{array}{l}\text { longitudinal } \\
\text { fins with } \\
\text { helium }\end{array}$ & $\begin{array}{c}40.76 \% \& \\
70.54 \%\end{array}$ & $\begin{array}{l}\text { Longitudinal fins } \\
\text { with air }\end{array}$ & $\begin{array}{c}41.97 \% \& \\
69.93 \%\end{array}$ & $\begin{array}{l}\text { Longitudinal fins } \\
\text { with } \mathrm{CO}_{2}\end{array}$ \\
\hline [37] & $\mathrm{Nu}(\%)$ & $(56-75) \%$ & $0.6 \%$ of $\mathrm{Fe} 304$ & $(59-73) \%$ & TT & $(63-7) \%$ & $\begin{array}{l}\text { TT and } 0.6 \% \text { of } \\
\mathrm{Fe}_{3} \mathrm{O}_{4}\end{array}$ \\
\hline
\end{tabular}




\begin{tabular}{|c|c|c|c|c|c|c|c|}
\hline [38] & $\begin{array}{l}\text { Performance evaluation criteria } \\
\text { (PEC) }\end{array}$ & $1.23-1.37$ & Dimples & $1.125-1.225$ & Helical fins & $1.13-1.41$ & Protrusions \\
\hline [39] & Heat losses (Watt) & 26.6 & $\begin{array}{l}\text { V-cavity } \\
\text { receiver }\end{array}$ & 16.3 & $\begin{array}{l}\text { V-cavity with } \\
\text { fins }\end{array}$ & - & - \\
\hline [40] & $\mathrm{Nu}$ (times), FF (times) \& PEC & $\begin{array}{l}10-12,400- \\
700,1.1-1.5\end{array}$ & $\begin{array}{l}\text { metal foam } \\
(\mathrm{H}=0.75 \text { top })\end{array}$ & $\begin{array}{l}5-10,10-20 \\
1.4-3.2\end{array}$ & $\begin{array}{c}\text { metal foam } \\
(\mathrm{H}=0.25 \text { bottom })\end{array}$ & - & - \\
\hline
\end{tabular}

\section{Summary}

To effectively enhance the optical and thermal efficiencies of PTCs, some possible solutions from the literature are summarized in this paper related to improvement of the thermal properties of HTF and manipulation of the optical design of HCE.

\section{Acknowledgment}

The authors would like to thank the UK's Department of Business, Energy and Industrial Strategy for the financial support through Newton institutional links fund (Engineering Sustainable Solar Energy and Thermocline Alternatives-ESSEnTiAl, Grant ID 332271136).

\section{References}

1. Philibert C, Frankl P (2010) International energy agency. Technology roadmap: concentrating solar power, Paris, France.

2. Odeh S, Morrison G, Behnia M (1998) Modelling of parabolic through direct steam generation solar collectors. Solar Energy 62(6): 395-406.

3. Forristall RE (2003) Heat transfer analysis and modeling of a parabolic trough solar receiver implemented in engineering equation solver. NREL, Bechtel, USA.

4. Montes MJ, Abánades A, Martínez-val JM (2010) Thermofluidynamic model and comparative analysis of PTCs using oil, water/steam, or molten salt as heat transfer fluids. J Sol Energy Eng 132(2): 021001.

5. Ouagued M, Khellaf A (2012) Simulation of the temperature and heat gain by solar parabolic trough collector in Algeria. International Journal of Mathematical, Computational, Physical, Electrical and Computer Engineering 6(7): 746-752.

6. Ouagued M, Khellaf A, Loukarfi L (2013) Estimation of the temperature, heat gain and heat loss by solar PTC under Algerian climate using different thermal oils. Energy Conversion and Management 75: 191-201.

7. Biencinto M, González L, Zarza E, Díez LE, Muñoz-antón J (2014) Performance model and annual yield comparison of parabolic-trough solar thermal power plants with either nitrogen or synthetic oil as heat transfer fluid. Energy Conversion and Management 87: 238-249.

8. Muñoz-anton J, Biencinto M, Zarza E, Diez LE (2014) Theoretical basis and experimental facility for PTCs at high temperature using gas as heat transfer fluid. Applied Energy 135: 373-381.

9. Wu YT, Liu SW, Xiong YX, Ma CF, Ding YL (2015) Experimental study on the heat transfer characteristics of a low melting point salt in a parabolic trough solar collector system. Applied Thermal Engineering 89: 748754.
10. Qiu Y, Li MJ, He YL, Tao WQ (2017) Thermal performance analysis of a parabolic trough solar collector using supercritical $\mathrm{CO}_{2}$ as heat transfer fluid under non-uniform solar flux. Applied Thermal Engineering 115: 1255-1265.

11. Tahtah R, Bouchoucha A, Benkafada F, Abid C, Kadja M (2017) Experimental study of heat transfer in parabolic trough solar receiver: Using two different heat transfer fluids. AIP Conference Proceedings 1814(1): 020051.

12. Bellos E, Tzivanidis C, Antonopoulos KA (2017) A detailed working fluid investigation for solar parabolic trough collectors. Applied Thermal Engineering 114: 374-386.

13. Paul TC, Morshed A, Fox EB, Khan JA (2015) Thermal performance of $\mathrm{Al}_{2} \mathrm{O}_{3}$ Nanoparticle Enhanced Ionic Liquids (NEILs) for Concentrated Solar Power (CSP) applications. International Journal of Heat and Mass Transfer. 85, 585-594.

14. Zadeh P, Sokhansefat T, Kasaeian AB, Kowsary F, Akbarzadeh A (2015) Hybrid optimization algorithm for thermal analysis in a solar PTC based on nanofluid. Energy 82: 857-864.

15. Sokhansefat T, Kasaeian A, Kowsary F (2015) Heat transfer enhancement in PTC tube using $\mathrm{Al}_{2} \mathrm{O}_{3}$ /synthetic oil nanofluid. Renewable and Sustainable Energy Reviews 33: 636-644.

16. Mwesigye A, Huan Z, Meyer JP (2015) Thermodynamic optimisation of the performance of a parabolic trough receiver using synthetic oil- $\mathrm{Al}_{2} \mathrm{O}_{3}$ nanofluid. Applied Energy 156: 398-412.

17. Menbari A, Alemrajabi AA, Ghayeb Y (2016) Investigation on the stability, viscosity and extinction coefficient of $\mathrm{CuO}-\mathrm{Al}_{2} \mathrm{O}_{3} /$ Water binary mixture nanofluid. Experimental Thermal and Fluid Science 74: 122-129.

18. Kaloudis E, Papanicolaou E, Belessiotis V (2016) Numerical simulations of a parabolic trough solar collector with nanofluid using a two-phase model. Renewable Energy 97: 218-229.

19. Aguilar $\mathrm{T}$ (2018 Investigation of enhanced thermal properties in NiO-based nanofluids for concentrating solar power applications: A molecular dynamics and experimental analysis.) Applied Energy 211: 677-688.

20. Menbari A, Alemrajabi AA, Rezaei A (2017) Experimental investigation of thermal performance for direct absorption solar PTC (DASPTC) based on binary nanofluids. Experimental Thermal and Fluid Science 80: 218227.

21. Wang Y, Xu J, Liu Q Chen Y, Liu H (2016) Performance analysis of a parabolic trough solar collector using $\mathrm{Al}_{2} \mathrm{O}_{3}$ /synthetic oil nanofluid. Applied Thermal Engineering 107: 469-478.

22. Rehan MA, Ali M, Sheikh NA, Khalil MS, Chaudhary GQ, et al. (2018) Experimental performance analysis of low concentration ratio solar parabolic trough collectors with nanofluids in winter conditions. Renewable Energy 118: 742-751. 
23. Subramani J, Nagarajan PK, Mahian O, Sathyamurthy R (2018) Efficiency and heat transfer improvements in a parabolic trough solar collector using $\mathrm{TiO}_{2}$ nanofluids under turbulent flow regime. Renew. Energy 119: 19-31.

24. Kasaeian A, Daviran S, Danesh Azarian R, Rashidi A (2015) Performance evaluation and nanofluid using capability study of a solar parabolic trough collector. Energy Convers Manag 89: 368-375.

25. Allouhi A, Benzakour Amine M, Saidur R, Kousksou T (2018) Energy and exergy analyses of a parabolic trough collector operated with nanofluids for medium and high temperature applications. Energy Conversion and Management 155: 201-217.

26. Mwesigye A, Huan Z, Meyer JP (2016) Thermal performance and entropy generation analysis of a high concentration ratio parabolic trough solar collector with $\mathrm{Cu}$-Therminol®VP-1 nanofluid. Energy Conversion and Management 120: 449-465.

27. Reddy K, Ravi Kumar K, Ajay C (2015) Experimental investigation of porous disc enhanced receiver for solar parabolic trough collector. Renewable Energy 77: 308-319.

28. Ghadirijafarbeigloo S, Zamzamian A, Yaghoubi M (2014). 3-D Numerical simulation of heat transfer and turbulent flow in a receiver tube of solar parabolic trough concentrator with louvered twisted-tape inserts. Energy Procedia 49: 373-380.

29. Ebrahim Ghasemi S, Akbar Ranjbar A (2017) Numerical thermal study on effect of porous rings on performance of solar parabolic trough collector. Applied Thermal Engineering 118: 807-816.

30. Xiangtao G, Wang F, Wang H, Tan J, Lai Q, et al. (2017) Heat transfer enhancement analysis of tube receiver for parabolic trough solar collector with pin fin arrays inserting. Solar Energy 144: 185-202.

31. Ghasemi SE, Ranjbar AA, Ramiar A (2013) Three-dimensional numerical analysis of heat transfer characteristics of solar parabolic collector with two segmental rings. Journal of Mathematics and Computer Science 7: 89-100.
32. Reddy KS, Satyanarayana GV (2008) Numerical study of porous finned receiver for solar parabolic trough concentrator. Engineering Applications of Computational Fluid Mechanics 2: 172-184.

33. Jafar KS, Sivaraman B (2014) Thermal performance of solar PTC using nanofluids and the absorber with nail twisted tapes inserts. International Energy Journal 14: 189-198.

34. Zheng L, Xie Y, Zhang D (2017) Numerical investigation on heat transfer performance and flow characteristics in circular tubes with dimpled twisted tapes using $\mathrm{Al}_{2} \mathrm{O}_{3}$-water nanofluid. International Journal of Heat and Mass Transfer 111: 962-981.

35. Amina B, Miloud A, Samir L, Abdelylah B, Solano JP (2016) Heat transfer enhancement in a parabolic trough solar receiver using longitudinal fins and nanofluids. Journal of Thermal Science 25(5): 410-417.

36. Bellos, E., Tzivanidis C, Daniil I, Antonopoulos KA (2017) The impact of internal longitudinal fins in parabolic trough collectors operating with gases. Energy Conversion and Management 135: 35-54.

37. Bilal FR, Arunachala UC, Sandeep HM (2018) Experimental validation of energy parameters in parabolic trough collector with plain absorber and analysis of heat transfer enhancement techniques J Phys: Conf Ser p. 953.

38. Huang Z, Yu G, Li Z, Tao W (2015) Numerical study on heat transfer enhancement in a receiver tube of parabolic trough solar collector with dimples, protrusions and helical fins. Energy Procedia 69: 1306-1316.

39. Xiao X, Zhang P, Shao D, Li M (2014) Experimental and numerical heat transfer analysis of a V-cavity absorber for linear parabolic trough solar collector. Energy Conversion and Management 86: 49-59.

40. Wang P, Liu D, Xu C (2013) Numerical study of heat transfer enhancement in the receiver tube of direct steam generation with parabolic trough by inserting metal foams. Applied Energy. 102: 449-460. 